University of Nebraska - Lincoln

DigitalCommons@University of Nebraska - Lincoln

Faculty Papers and Publications in Animal

Science

Animal Science Department

1986

\title{
Growth, Carcass and Palatability Traits of Intact Males and Steers Implanted With Zeranol or Estradiol Early and Throughout life
}

\author{
Chris R. Calkins \\ University of Nebraska-Lincoln, ccalkins1@unl.edu \\ D. C. Clanton \\ West Central Res. and Ext Center, don_clanton@comcast.net \\ T. J. Berg \\ West Central Res. and Ext Center \\ J. E. Kinder \\ University of Nebraska-Lincoln, kinder.15@osu.edu
}

Follow this and additional works at: https://digitalcommons.unl.edu/animalscifacpub

Part of the Animal Sciences Commons

Calkins, Chris R.; Clanton, D. C.; Berg, T. J.; and Kinder, J. E., "Growth, Carcass and Palatability Traits of Intact Males and Steers Implanted With Zeranol or Estradiol Early and Throughout life" (1986). Faculty Papers and Publications in Animal Science. 568.

https://digitalcommons.unl.edu/animalscifacpub/568

This Article is brought to you for free and open access by the Animal Science Department at DigitalCommons@University of Nebraska - Lincoln. It has been accepted for inclusion in Faculty Papers and Publications in Animal Science by an authorized administrator of DigitalCommons@University of Nebraska - Lincoln. 


\title{
GROWTH, CARCASS AND PALATABILITY TRAITS OF INTACT MALES AND STEERS IMPLANTED WITH ZERANOL OR ESTRADIOL EARLY AND THROUGHOUT LIFE ${ }^{1}$
}

\author{
C. R. Calkins ${ }^{2}$, D. C. Clanton ${ }^{3}$, T. J. Berg ${ }^{3}$ and J. E. Kinder ${ }^{2}$ \\ University of Nebraska ${ }^{2}$, Lincoln 68583
}

\begin{abstract}
This study was conducted to assess the impact of implanting intact beef males with protein anabolic agents at varying intervals throughout life. Ninety-six intact males were assigned to three implant treatments: 1) not implanted, 2) implanted at 9 wk of age, weaning and at 56-d intervals thereafter with a $36-\mathrm{mg}$ zeranol implant or 3 ) estradiol implant at 9 wk of age and $68 \mathrm{~d}$ postweaning. During the 118-d, post-weaning growing period, eight animals per treatment (one replication) were castrated. After a 114-d finishing period, cattle were slaughtered (average age of 13 to $14 \mathrm{mo}$ ). Feedlot performance, carcass and palatability data were obtained. Average daily gains and feed efficiency did not differ ( $P>.05)$ between zeranol and estradiol-implanted intact males. Regardless of implant treatment, steers had lighter carcass weights $(P<.05)$ and higher $(P<.01)$ quality grades than intact males. Implanting either intact males or steers with zeranol or estradiol resulted in higher $(P<.05)$ numerical yield grades. Quality grades were higher in zeranol-implanted cattle than the non-implanted or estradiol-implanted cattle. Intact males implanted with zeranol were similar in carcass fatness to zeranol-implanted steers. No differences $(P>.05)$ in tenderness or connective tissue were detected. Implanting intact males early and throughout life with zeranol made them similar to steers in fatness, while estradiol implantation had few effects on carcass and palatability traits of intact males or steers.

(Key Words: Growth Promoters, Bulls, Steers.)
\end{abstract}

\section{Introduction}

Considerable research has been conducted to examine the efficiency of feeding young intact males for slaughter. Generally, it has been reported that young intact males gain faster and more efficiently than do steers (Seideman et al., 1982). However, recent research also has emphasized that, when fed to the same compositional endpoint, steers can attain the desired endpoint more quickly and efficiently than can intact males (Crouse et al., 1984). In an effort to capitalize on the growth rates of young intact males and to produce meat of similar composition and palatability to steers, recent attention has focused on the use of growth-promoting implants in young intact males. In general, three regimens of implantation have been investigated: implanting at the

\footnotetext{
${ }^{1}$ Published as Paper Number 7747, Journal Series, Nebraska Agr. Exp. Sta.

${ }^{2}$ Dept. of Anim. Sci.

${ }^{3}$ West Central Res. and Ext. Center.

Received March 11, 1985.

Accepted October 3, 1985.
}

beginning of the finishing phase (Gregory et al., 1983; Johnson et al., 1984; Schanbacher et al., 1984); at or near weaning and during the growing and finishing periods (Forrest, 1975; Johnson and Gee, 1982; Newland et al., 1984; Vanderwert et al., 1984); or implanting near birth and at pre-planned intervals throughout life (Ralston, 1978; Lamm et al., 1980; Brethour, 1982; Greathouse et al., 1983; Gray et al., 1984; Unruh et al., 1984). Most of this recent research deals with zeranol as a growth promotant. The utility of lifelong implantation with estradiol has not been investigated. Most research with estradiol deals with implanting animals after weaning, during the growing and(or) finishing periods. Results from the previously cited papers emphasize two concepts: first, the age of the animal and the duration of exposure to hormone-implant treatments are important in determining the magnitude of response; and second, that little agreement has been reached regarding the efficacy of implanting intact males with the protein anabolic agents zeranol or estradiol. With the current heightened interest in use of estradiol- $17 \beta$ as a growth promotant, and an absence of informa- 
tion regarding the effects of lifelong implantation of intact males with this hormone, our research was conducted to assess the impact of implanting young intact males, early and throughout life, with selected growth promotants on growth, carcass and palatability traits.

\section{Experimental Procedure}

Ninety-six intact males from primiparous Angus $x$ Hereford dams and MARC Il sires (one-fourth each of Angus, Gelbvieh, Hereford and Simmental) were assigned randomly to one of three treatments: 1) not implanted, 2) zeranol (Ralgro ${ }^{\circledR}$, implanted five times with a 36-mg implant; at $9 \mathrm{wk}$ of age, at weaning and at 56-d intervals thereafter) or 3 ) estradiol- $17 \beta$ (Compudose ${ }^{\circledR}, 200-\mathrm{d}$ implant, implanted twice; at $9 \mathrm{wk}$ of age and $68 \mathrm{~d}$ post-weaning). Following weaning, at about 6 mo of age, the calves were allotted to four replications of each treatment and fed a corn-and-silage based growing diet (calculated net energy for maintenance was $1.78 \mathrm{Mcal} / \mathrm{kg}$ of dry matter; net energy for gain was $1.18 \mathrm{Mcal} / \mathrm{kg}$ of dry matter) for $118 \mathrm{~d}$. One replication of each treatment was castrated $70 \mathrm{~d}$ after the beginning of the growing period (about 9 mo of age) to provide a steer comparison for carcass data. The cattle were fed a highenergy finishing diet (calculated net energy for maintenance was $1.97 \mathrm{Mcal} / \mathrm{kg}$ of dry matter; net energy for gain was $1.35 \mathrm{Mcal} / \mathrm{kg}$ of dry matter) for $114 \mathrm{~d}$ prior to slaughter at 13 to 14 mo of age. At the start of the growing and finishing periods, a full weight was taken on each animal to facilitate calculation of average daily gain (ADG) and feed efficiency (kg of dry matter per $\mathrm{kg}$ of gain). Final weights were calculated from hot carcass weight on the basis of $62 \%$ dressing percent.

Blood samples were obtained from all animals on $\mathrm{d} 63$ during the growing period and d 1,49 and 114 during the finishing period. Serum testosterone concentrations were determined by the radioimmunoassay techniques of Kiser et al. (1978).

The cattle were shipped about $400 \mathrm{~km}$ to a commercial slaughter plant and slaughtered immediately upon arrival. After a 48-h chilling period, USDA quality and yield grade factors were obtained along with muscle color, firmness and texture scores. Wholesale ribs were obtained from the steer carcasses ( $n=8$ per implant group) and from randomly selected carcasses from intact males ( $n=12$ per implant group).
The ribs were marked for removal of the 9-10-11th rib sections according to the procedures of Hankins and Howe (1946) and shipped to the University of Nebraska meat laboratory. At $10 \mathrm{~d}$ postmortem, the ribs were cut into 9-10-11th rib sections, frozen, and later thawed and dissected into separable lean, fat and bone. The separable lean and fat fractions were analyzed separately for fat and moisture using standard AOAC procedures (1975). Following the procedures of Hankins and Howe (1946), the percentage of ether-extractable fat of the edible portion of the dressed carcass was calculated based on the percentage of fat in the rib section and upon the percentage of fat in the longissimus muscle.

At the time of rib section removal, individual longissimus muscle steaks were obtained for determination of total and heat soluble collagen by the procedures of Hill (1966) and Bergman and Loxley (1963).

Steaks were obtained from the wholesale ribs, frozen and later thawed for cooking. Steaks were cooked on roasting pans in a $177 \mathrm{C}$ rotary hearth oven to an internal temperature of $70 \mathrm{C}$ (monitored by small diameter, copperconstantan thermocouples). Steaks were turned over when they reached $35 \mathrm{C}$ internal temperature. Samples were then evaluated by a trained (Cross et al., 1978) sensory panel for juiciness, muscle fiber tenderness and connective tissue amount. Ratings were made on a $15-\mathrm{cm}$ unstructured line scale with the extremes labeled as tough, abundant connective tissue or dry on one end of the line and tender, no connective tissue or juicy on the opposite end. WarnerBratzler shear force values were obtained on $1.3-\mathrm{cm}$ cores using an Instron Universal Testing Machine.

Data were analyzed using the Statistical Analysis System (SAS, 1982). Analysis of variance was conducted using a model which contained replication, sex, implant treatment and sex $X$ implant treatment as sources of variation. Experimental error and sampling error were pooled, where appropriate. Significant interactions or, in their absence, main effects were evaluated using the new Duncan's multiplerange procedure to test for differences among treatment means.

\section{Results and Discussion}

Growth Traits. Table 1 presents the production data for intact males. Since only one replication of steers was fed, production data of 
TABLE 1. EFFECTS OF IMPLANTS ON PERFORMANCE OF INTACT MALES

\begin{tabular}{|c|c|c|c|c|}
\hline \multirow[b]{2}{*}{ Trait } & \multicolumn{3}{|c|}{ Implant treatment } & \multirow[b]{2}{*}{ SE } \\
\hline & Control & Zeranol & Estradiol & \\
\hline Weaning wt, kg & 164 & 168 & 171 & 4.4 \\
\hline Finished wt, kg & 472 & 490 & 488 & 8.9 \\
\hline Growing ADG, kg/d & $1.43^{\mathrm{b}}$ & $1.54 \mathrm{C}$ & $1.48^{\mathrm{bc}}$ & .07 \\
\hline Growing $F / G^{a}$ & $4.23^{b}$ & $4.19 b$ & $4.46^{\mathrm{c}}$ & .06 \\
\hline Finishing ADG, kg/d & 1.24 & 1.23 & 1.26 & .08 \\
\hline Finishing $F / G^{a}$ & 5.95 & 6.25 & 6.16 & .21 \\
\hline Combined ADG, $\mathrm{kg} / \mathrm{d}$ & 1.33 & 1.39 & 1.37 & .06 \\
\hline Combined $F / G^{\mathbf{a}}$ & 5.00 & 5.08 & 5.22 & .08 \\
\hline Testicle wt, g & $452^{\mathrm{b}}$ & $186^{\mathrm{C}}$ & $235^{\mathrm{C}}$ & 20.3 \\
\hline Testosterone, $\mathrm{ng} / \mathrm{ml}$ & $10.5^{b}$ & $4.9 \mathrm{~d}$ & $6.5^{\mathrm{c}}$ & .54 \\
\hline
\end{tabular}

${ }^{a} \mathrm{~F} / \mathrm{G}$ is $\mathrm{kg}$ of dry matter intake per $\mathrm{kg}$ of gain.

$b, c, d$ Means in the same row that do not have a common superscript are different $(P<.05)$.

steers were not evaluated. Weaning and finishing weights did not differ among treatments. Cattle implanted with zeranol gained faster $(\mathrm{P}<.05)$ during the growing period than the non-implanted intact males but were not more efficient. Cattle implanted with zeranol did not gain faster $(P>.05)$ than those implanted with estradiol but were more efficient during the growing period. There were no differences in gains or efficiencies between intact males receiving the different implant treatments during the finishing period, or for the growing and finishing periods combined. Vanderwert et al. (1984) reported similar results, but the cattle in their study were not implanted until the post-weaning growth period was initiated. Using estradiol implants post-weaning, Newland et al. (1984) reported no early advantage in postweaning ADG; when the overall growing and finishing periods were combined, however, ADG was increased for implanted intact males. Estradiol implants at $9 \mathrm{wk}$ of age did not affect performance of the cattle in our study.

Regardless of implant treatment, young intact males in our study exhibited better feed efficiency and more rapid gains during the growing period than during the finishing period (table 1). Growth of the calves might have been influenced by parity of the dams, i.e., some post-weaning compensatory growth may have occurred as a result of insufficient milk production from primiparous mothers. Also, differences in rate and efficiency of gain may be explained, in part, by changes in composition of gain during finishing.
Testicular weights and testosterone levels indicate that the implants were retained and were effective in altering normal testosteone secretion of the intact males (table 1). These results are consistent with previous research where scrotal circumference or testicular weight was studied (Lamm et al., 1980; Brethour, 1982; Greathouse et al., 1983; Unruh et al., 1984). Vanderwert et al. (1984), however, did not observe changes in scrotal circumference for intact males that were implanted with zeranol during the post-weaning period.

It has been suggested that the action of the estradiol implant is mediated through changes in luteinizing hormone secretion (D'Occhio et al., 1984), or by blocking gonadotropin release at the level of the hypothalamus (Schanbacher, 1984). The net effect of estradiol implantation is an increase in lipogenic activity, while lipolytic activity seems to remain unchanged (Prior et al., 1984).

Carcass Traits. Factors influenced by sex (main effect) are presented in table 2. For these traits, significant interactions were not observed. Intact male calves had heavier $(P<.05)$ carcass weights and less $(P<.01)$ subcutaneous fat, which resulted in lower $(P<.01)$ numerical yield grades. No differences $(P>.05)$ were evident in skeletal maturity, whereas steer carcasses possessed slightly higher quality grades $(\mathrm{P}<.01)$. These results are consistent with numerous reports in the literature concerning the carcass characteristics of intact males and steers (Seideman et al., 1982). Gray et al. (1983) reported that intact males implanted 
TABLE 2. EFFECTS OF SEX CLASS ACROSS IMPLANT TREATMENTS ON CARCASS CHARACTERISTICS

\begin{tabular}{lccccc} 
& \multicolumn{2}{c}{ Intact males } & & \multicolumn{2}{c}{ Steers } \\
\cline { 2 - 3 } \cline { 5 - 6 } Trait & Mean & $\mathrm{SE}^{\mathrm{a}}$ & & Mean & $\mathrm{SE}^{\mathrm{a}}$ \\
\hline \% Fat, carcass $\mathrm{b}$ & $31.91 \mathrm{~g}$ & .43 & & $38.84 \mathrm{~h}$ & .57 \\
Yield grade & $3.08 \mathrm{~h}$ & .08 & & $3.77^{\mathrm{h}}$ & .11 \\
Carcass wt, $\mathrm{kg}$ & $299 \mathrm{e}$ & 3.36 & & $283^{\mathrm{f}}$ & 5.39 \\
Adjusted fat thickness, cm & $1.34 \mathrm{~g}$ & .02 & & $1.75^{\mathrm{h}}$ & .03 \\
Quality gradec & 5968 & 6.1 & $609^{\mathrm{h}}$ & 8.1 \\
Maturityd & 151 & 1.1 & 148 & 2.6 \\
\hline
\end{tabular}

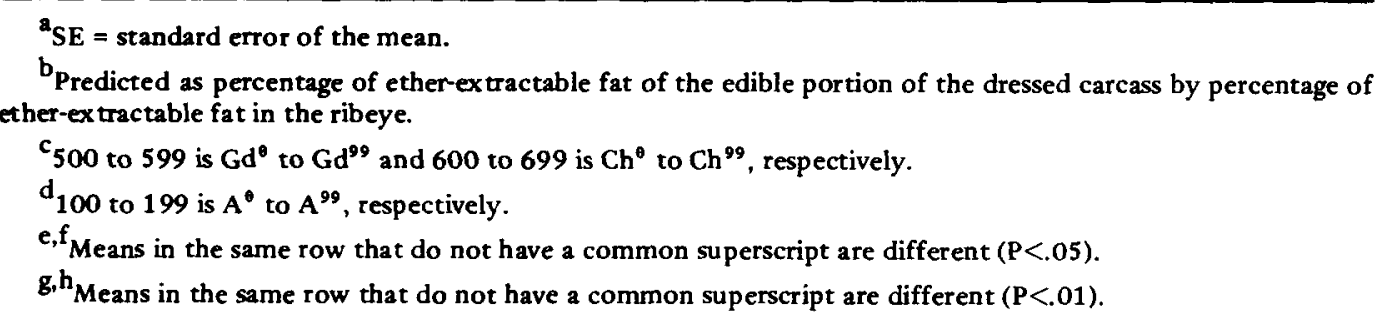

with zeranol from birth to slaughter were less masculine than non-implanted intact males.

Muscle color, firmness and texture were not influenced by sex class and(or) implant treatment (data not shown). Similar results for lean color and texture were reported by Gray et al. (1983) when zeranol-implanted intact males (implanted from birth to slaughter) were compared with non-implanted intact males.

The effects of implants on carcass traits of intact males and steers are shown in table 3. Non-implanted cattle had lighter $(P<.05)$ car- $^{-}$ casses, less $(P<.05)$ subcutaneous fat and lower $(P<.05)$ numerical yield grades than either implant treatment. This concurs with the data of Brethour (1982) and Newland et al. (1984).
Zeranol-implanted cattle had more $(\mathrm{P}<.05)$ external fat and had higher $(\mathrm{P}<.05)$ USDA quality grades than did the non-implanted and the estradiol-implanted cattle. Brethour (1982), Gray et al. (1984) and Vanderwert et al. (1984) have reported that implanting intact males with zeranol increases carcass fatness.

A study similar in design to the present study was reported by Johnson et al. (1984). Very few implant effects on carcass fatness were detected in their study, and it was concluded that producers should expect no improvement in USDA quality grade of implanted intact males. However, the cattle used in the study by Johnson et al. (1984) were implanted at initiation of the finishing period, and were

TABLE 3. EFFECTS OF IMPLANTS ACROSS SEX CLASSES ON CARCASS CHARACTERISTICS

\begin{tabular}{lcccr}
\hline & & Implant treatment & & \\
\cline { 2 - 5 } Trait & Control & Zeranol & Estradiol & SE \\
\hline Yield grade & $2.85^{\mathrm{d}}$ & $3.57^{\mathrm{c}}$ & $3.43^{\mathrm{c}}$ & .07 \\
Carcass wt, kg & $283^{\mathrm{d}}$ & $303^{\mathrm{c}}$ & $301^{\mathrm{c}}$ & 2.93 \\
Adjusted fat thickness, cm & $1.21^{\mathrm{e}}$ & $1.70^{\mathrm{c}}$ & $1.49^{\mathrm{d}}$ & .05 \\
Quality grade & $593^{\mathrm{d}}$ & $607^{\mathrm{c}}$ & $598^{\mathrm{d}}$ & 5.2 \\
Maturityb & $146^{\mathrm{c}}$ & $151^{\mathrm{d}}$ & $155^{\mathrm{d}}$ & 1.0 \\
\hline
\end{tabular}

\footnotetext{
a 500 to 599 is $\mathrm{Gd}^{8}$ to $\mathrm{Gd}^{99}$ and 600 to 699 is $\mathrm{Ch}^{\circ}$ to $\mathrm{Ch}^{99}$, respectively.

$b_{100}$ to 199 is $A^{0}$ to $A^{99}$, respectively.

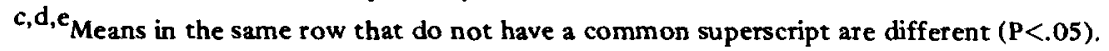


TABLE 4. INTERACTION MEANS FOR THE EFFECTS OF SEX CLASS AND IMPLANT TREATMENT

ON CARCASS CHARACTERISTICS

\begin{tabular}{|c|c|c|c|c|c|c|c|c|}
\hline \multirow[b]{3}{*}{ Trait } & \multicolumn{6}{|c|}{ Implant treatment } & & \\
\hline & \multicolumn{2}{|c|}{ Control } & \multicolumn{2}{|c|}{ Zeranol } & \multicolumn{2}{|c|}{ Estradiol } & \multicolumn{2}{|c|}{ SE } \\
\hline & $\begin{array}{l}\text { Intact } \\
\text { males }\end{array}$ & Steers & $\begin{array}{l}\text { Intact } \\
\text { males }\end{array}$ & Steers & $\begin{array}{l}\text { Intact } \\
\text { males }\end{array}$ & Steers & $\begin{array}{l}\text { Intact } \\
\text { males }\end{array}$ & Steers \\
\hline$\%$ Fat, rib section & $34.86^{\mathrm{de}}$ & 43.48 & $41.31^{\mathrm{c}}$ & 43.90 & $37.11 \mathrm{de}$ & 46.45 & .81 & .93 \\
\hline \% Fat, carcass ${ }^{a}$ & $29.29 \mathrm{de}$ & 35.66 & $34.06^{\mathrm{c}}$ & 35.98 & 30.95 de & 37.86 & .60 & .69 \\
\hline Juiciness $b$ & $8.29 \mathrm{ce}$ & 9.95 & $10.24 \mathrm{de}$ & 8.61 & $8.80^{c}$ & 9.62 & .17 & .23 \\
\hline Muscle fiber tenderness ${ }^{b}$ & $9.35 \mathrm{c}$ & $10.45 \mathrm{x}$ & $9.95 \mathrm{c}$ & $9.06 y$ & $9.25^{c}$ & $9.39 x y$ & .17 & .21 \\
\hline Warner-Bratzler shear force, $\mathrm{kg}$ & 2.31 & 2.16 & 2.32 & 2.31 & 2.20 & 2.33 & .05 & .08 \\
\hline Connective tissue amount $\mathrm{b}^{\mathrm{b}}$ & 11.28 & 11.88 & 11.44 & 11.45 & 11.44 & 11.67 & .16 & .18 \\
\hline Total collagen, $\mathrm{mg} / \mathrm{g}$ of tissue & 9.56 & 8.12 & 7.28 & 6.65 & 8.96 & 7.55 & .56 & .51 \\
\hline Collagen, $\%$ soluble & 41.89 & 37.84 & 37.66 & 41.13 & 43.29 & 38.96 & 1.11 & 1.73 \\
\hline
\end{tabular}

${ }^{a}$ Predicted as percentage of ether-extractable fat of the edible portion of the dressed carcass by percentage ether-extractable fat in the $9-10-11$ th rib section.

$\mathrm{b}_{\text {Taste panel rating }}(\mathbf{1}=$ tough, abundant connective tissue, or dry; $15=$ tender, no connective tissue, or juicy).

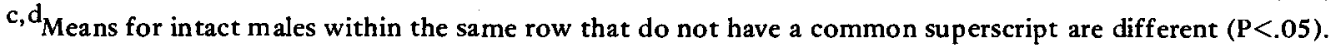

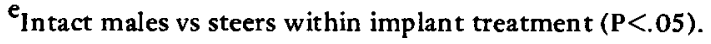

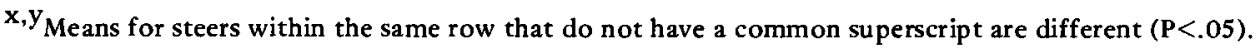


not subjected to lifelong implantation. The age of the animal at the time of implanting and the length of time that the body is exposed to the exogenous hormone seem to play a critical role in determining the extent to which implant effects will be manifested.

Palatability and Connective Tissue. The seximplant interactions are presented in table 4 . Measurements of fatness, either of the 9-1011 th rib-section, or predicted for the edible carcass portion, indicate that zeranol-implanted intact males had greater lipid $(P<.05)$ deposition than estradiol-implanted or control intact males. There were no differences among steer groups for measures of fatness. Zeranolimplanted intact males were equal in fatness to zeranol-implanted steers. Estradiol-implanted or non-implanted intact males were leaner $(\mathrm{P}<.05)$ than steers.

Juiciness tended to reflect differences in fatness (table 4). Zeranol-implanted intact males provided steaks that were juicier $(\mathrm{P}<.05)$ than the leaner steaks from non-implanted or estradiolimplanted intact males. As with fatness, no differences $(P>.05)$ in juiciness were observed among steer groups.

Implantation treatment had very little effect on muscle fiber tenderness ratings (table 4). Steaks from zeranol-implanted steers were found to be less tender $(\mathrm{P}<.05)$ than steaks from control steers. Direct comparisons between intact males and steers were not different $(P>.05)$. When tenderness was assessed using the Warner-Bratzler shear, no differences were observed for any of the comparisons. These data indicate that the accelerated production system used in our study was sufficient to ensure adequate tenderness.

Connective tissue was evaluated by the taste panel (table 4 ) and no differences $(P>.05$ ) were found. In addition, laboratory determination of total and percentage of soluble collagen also failed to detect differences among treatments.

\section{Conclusions}

Lifelong implantation of intact males with zeranol or estradiol did not alter gain or feed efficiency. when the growing and finishing phases were combined. Yield grades of intact males and steers were numerically increased by implantation with zeranol or estradiol. However, only zeranol implantation significantly increased fatness of the rib-section (or estimated fatness of the edible carcass portion) for intact males to the level of zeranol-implanted steers.
Juiciness ratings tended to reflect differences in fatness. No detrimental effects on tenderness or connective tissue were observed.

These results and those of Greathouse et al. (1983) and Gray et al. (1983) show that zeranol implantation of young intact males improves traits often cited by meat packers and processors as reasons for discriminating against young intact males. Masculinity was decreased (Gray et al., 1983) and quality grade, fat thickness and longissimus sensory-panel juiciness were increased. From a production standpoint, performance was at least equal, and carcass weight was increased, in these medium-framed intact males. Although zeranol- and estradiol17 -implanted intact males had more fat than non-implanted intact males, this disadvantage could be alleviated by slaughtering at lighter weights.

\section{Literature Cited}

AOAC. 1975. Official Methods of Analysis (12th Ed.). Association of Official Analytical Chemists, Washington, DC.

Bergman, I. and Loxley, R. 1963. Two improved and simplified methods for the spectrophotometric determination of hydroxyproline. Anal. Chem. $35: 1961$.

Brethour, J. R. 1982, Nutrition research with intact males and steers. Kansas Agr. Exp. Sta., Proc. U.S. Beef Symp, p 41.

Cross, H. R., R. Moen and M. S. Stanfield. 1978. Training and testing of judges for sensory analysis of meat quality. Food Technol. $32(7): 48$.

Crouse, J. D., C. L. Ferrell, L. V. Cundiff and S. C. Seideman. 1984. Effects of sex condition, genotype and diet on bovine performance, carcass merit and meat sensory characteristics. J. Anim. Sci. 59(Suppl. 1):396.

D'Occhio, M. J., B. D. Schanbacher and J. E. Kinder. 1984. In vitro testosterone secretion by testicular tissue from young bulls and the effects of chronic and acute exposure to estradiol-17 $\beta$. J. Anim. Sci. 58:949.

Forrest, R. J. 1975. Effects of castration, sire and hormone treatments on the quality of rib roasts from Holstein-Friesian males, Can. J. Anim. Sci. $55: 287$.

Gray, D. G., J. A. Unruh and M. E. Dikeman. 1984. Performance and carcass characteristics of zeranol implanted bulls slaughtered at four ages. J. Anim. Sci. 59(Suppl. 1):396.

Gray, D. G., J. A. Unruh, M. E. Dikeman and L. R. Corah. 1983. Effects of zeranol implantation periods on carcass characteristics of young bulls and steers. J. Anim. Sci. 57 (Suppl. 1):218.

Greathouse, J. R., M. C. Hunt, M. E. Dikeman, L. R. Corah, C. L. Kastner and D. H. Kropf. 1983. Ralgro-implanted bulls: Performance, carcass characteristics, longissimus palatability and carcass electrical stimulation. J. Anim. Sci. 57: 
355.

Gregory, K. E., S. C. Seideman and J. J. Ford, 1983. Effects of late castration, zeranol and breed group on composition and palatability characteristics of longissimus muscle of bovine males. $J$. Anim. Sci. 56:781.

Hankins, O. G. and P. E. Howe. 1946. Estimation of the conposition of beef carcasses and cuts. USDA Tech. Bull. No. 926.

Hill, F. 1966. The solubility of intramuscular collagen in meat animals of various ages. J. Food Sci. 31: 161.

Johnson, D. D., J. W. Savell, G. C. Smith, D. R. Gill, D. E. Williams, L. E. Walters and J. J. Martin. 1984. Relationship of growth stimulants and breed groups on carcass characteristics and palatability of young bulls. J. Anim. Sci. 58:920.

Johnson, R. C. and D. H. Gee. 1982. Effect of breed and implant on carcass traits and palatability of bullock beef. Proc. Recip. Meats Conf., Amer. Meat Sci. Assoc. 35:56.

Kiser, T. E., R. A. Milvae. H. D. Hafs, W. D. Oxender and T. M. Louis. 1978. Comparison of testosterone and androstenedion secretion in bulls given prostaglandin $F_{2}$ or luteinizing hormone. J. Anim. Sci. $46: 436$.

Lamm, W. D., R. F. Kelly, w. H. McClure and J. P. Fontenot. 1980. Effect of zeranol implants on performance of suckling calves and growingfinishing bulls and heifers. J. Anim. Sci. 51 (Suppl. 1):377.

Newland, H. W., G. R. Wilson, R. R. Reed, B. D. VanStavern, and W. R. Harvey. 1984. Effect of Ralgro, Compudose, and the combination of both at two energy rates on feedlot performance of young bulls. Ann. Rep. NCR-132. The use of non-castrated meat a nimals for food.

Prior, R. L., S. B. Smith, B. D. Schanbacher and H. J. Mersmann. 1984. Lipid metabolism in finishing bulls and steers implanted with oestradiol-17 $\beta$ dipropionate. Ann. Rep. NCR-132. The use of non-castrated meat animals for food.

Ralston, A. T. 1978. Effect of zeranol on weaning weight of male calves. J. Anim. Sci. 47:1203.

SAS. 1982. SAS User's Guide: Statistics. Statistical Analysis System Inst., Inc., Cary, NC.

Schanbacher, B. D. 1984. Pituitary-testicular responses of estradiol-17 $\beta$-implanted bull calves to continuous versus pulsatile infusion of luteinizing hormone releasing hormone. J. Anim. Sci. 58: 943.

Schanbacher, B. D., R. L. Prior and S. B. Smith. 1984. Effects of castration and subdermal silastic implants containing oestradiol-17 $\beta$-dipropionate on feedlot performance and carcass characteristics of male cattle. Ann. Rep. NCR-132. The use of noncastrated meat animals for food.

Seideman, S. C., H. R. Cross, R. R. Oltjen and B. D. Schanbacher. 1982. Utilization of the intact male for red meat production: A review. J. Anim. Sci. $55: 826$.

Unruh, J. A., D. G. Gray and M. E, Dikeman. 1984. Effects of zeranol implantation from birth to slaughter on behavior and masculinity of young bulls fed to four slaughter ages. J. Anim. Sci. 59 (Suppl. 1):396.

Vanderwert, W., L. L. Berger, F. K. McKeith, P. J. Bechtel and T. R. Carr. 1984. Influence of Zeranol dosage level in Angus bulls and late castrate cattle. J. Anim. Sci. 59(Suppl, 1):397. 